Pain Physician. 2003;6:485-494, ISSN 1533-3159

\title{
The Evolution of Interventional Pain Management
}

\author{
Laxmaiah Manchikanti, MD, Mark V. Boswell, MD, PhD, P. Prithvi Raj, MD, and Gabor B. Racz, MD
}

Interventional pain management dates back to the origins of neural blockade and regional analgesia. Over the years, it evolved into a distinct specialty with the application of interventional techniques beyond those of simple neural blockade. The first therapeutic nerve block in pain management was described in 1899 by Tuffer. Subsequently, numerous techniques of interventional pain management with neural blockade were de-

Albert Schweitzer, the humanitarian, physician, and Nobel lauréate in 1931, elegantly described the nature of pain and the obligation and privilege of the physician and other healthcare professionals to relieve it (1). He eloquently stated, "We must all die. But that I can save him from days of torture, that is what I feel is my great and ever new privilege. Pain is a more terrible lord of mankind than even death itself." Today, proper management of pain remains one of the most important and pressing issues of society in general and the scientific community and the health professions in particular (2). Many have described the concept and treatment of pain from primitive times to recent advances in pain research and therapy, along with goals for improving the management of chronic persistent pain (2-9).

As history repeats itself, pain has been a major concern of mankind since our beginnings, and it has been the object of continual efforts to understand and control it. Fulop-Mueller (4) described pain as being even older than mankind, as pain is inherent in any life linked with consciousness. According to a World

From Pain Management Center of Paducah, Paducah, KY, Case Western Reserve University, Cleveland, Ohio, and Texas Tech University Health Sciences Center, Lubbock, TX. Address Correspondence: Laxmaiah Manchikanti, MD, 2831 Lone Oak Road, Paducah, KY-42003.

E-mail:drm@apex.net

Funding: There was no external funding in preparation of this manuscript. scribed. Diagnostic blockade in pain management was pioneered by von Gaza with the use of procaine for determining the pathways of obscure pain. Interventional pain management has entered into the modern era in the twenty-first century, driven by contributions from pioneers including Bonica, Winnie, Raj, Racz, Bogduk, and others.

This historical review examines the origins of interventional pain management, its pathophysiologic basis, the role of precision diagnostic interventional techniques, therapeutic interventional techniques, and the future of interventional pain management.

Keywords: Interventional pain management, evolution, regional anesthesia, neural blockade, precision diagnostic interventional techniques, therapeutic interventional techniques, future
Health Organization study, $22 \%$ of primary care patients reported persistent pain (10). Harstall (11) noted that the prevalence of chronic pain ranges from $10 \%$ to $55 \%$, in a review he made of 13 studies published between 1991 and 2002. Seven other studies $(10,12-17)$ using the International Association for the Study of Pain (18) definition of chronic pain, reported a prevalence of $11.5 \%$ to $55.2 \%$. Chronic widespread pain has been reported to range from $10.1 \%$ to $13 \%$ (19-21), utilizing the American College of Rheumatology definition of chronic widespread pain (22). The prevalence of chronic pain in the elderly has been reported to be $23.7 \%$ to $50.2 \%(17,23)$. Schnitzer (24) found that in the United States alone, 75 million adults experience chronic pain. In modern times, chronic pain not only continues to be an epidemic but is coupled with claims of inadequate treatment (10-17, 19-58). Chronic pain affects people from all walks of life, including men and women of all ages, working and non-working, from all countries, physically fit and disabled, suffering all types of injuries, working in every occupation, with or without psychological problems, and with or without drug abuse (10-17, 19-58). The social and economic impact of chronic pain on society is enormous (59-69).

There has been a growing scientific interest in pain over the past several decades. The field of pain management has undergone a revolution, particularly in the last 40 years. The understanding of pain has moved forward, occasionally with leaps and bounds, from Descartes' early conceptions of the pain pathway to Melzack and Wall's gate control theory $(8,70)$. Advances have been made by basic scientists and clinical researchers alike, representing numerous disciplines -- including anesthesiology, surgery, rehabilitation, epidemiology, nursing and psychology -- making immense contributions (71). Despite the advances $(8,72$, 73 ), even in 2003, our understanding of pain, and its diagnosis and treatment, remains cursory at best..

Over the years, pain management has taken on many forms. Chronic pain has been recognized as not only a multifactorial disorder with many possible etiologies, but also as a multidimensional problem with sensory and affective components. The father of the field of pain management as we know it today, was John Bonica who tirelessly pioneered the development of the multidisciplinary concept of pain research and treatment from the end of World War II until his death in 1994 (74).

The biopsychosocial model, which emerged in the 1980s, views chronic pain as a biopsychosocial phenomenon, in which biological, psychological, and social factors dynamically interact with each other. In the 1990s, functional rehabilitation emerged as the dominant mode of therapy in chronic spinal pain. Thus, the approach to pain management currently includes psychological, behavioral, functional, and interventional pain therapies. 


\section{Historical Considerations}

Interventional pain management dates back to the origins of neural blockade and regional analgesia. Fundamental to modern neural blockade and interventional techniques is the concept that pain is a sensory warning conveyed by specific nerve fibers, amenable, in principle, to modulation or interruption anywhere in the nerve's pathway. The concepts of neural blockade and interventional techniques are founded on the structural basis of chronic pain.

The origins of neural blockade and regional anesthesia date back to September 15, 1884, when Koller (a colleague of Sigmund Freud)reported the numbing effect of cocaine on the tongue (74). This observation took the world by storm. By the year's end, cocaine was used to provide effective local anesthesia for ophthalmology, urology, and general surgery. In 1899, Tuffer (75) described a therapeutic nerve block in pain management, using spinal cocaine to control pain from sarcoma of the leg. Further progress was advanced when Cushing (76) described pain relief with nerve blocks, caudal epidural injections were described in 1901 (77-79); trigeminal alcohol blockade was reported by Schloesser (80) in 1903; and by a rapidly growing list of interventional techniques (81-141).

Diagnostic blockade in pain management was pioneered when von Gaza (142) used procaine for determining the pathways of obscure pain (sympathetic or sensory). Following this, White (143) in 1930, and Steindler and Luck (144) in 1938, described applications for diagnostic interventional techniques.

The futility of treating pain without localizing the pain generator prompted Steindler and Luck (144) to employ procaine hydrochloride injections for identifying specific sources of pain in low back pain disorders. The application of clinical anatomy and an appreciation of the structural basis of spinal pain revolutionized diagnostic interventional techniques.

Recent advances in our understanding of key principles of clinical anatomy of the spine, particularly for interventionalists, are credited to Bogduk and others (145-159).

\section{Diagnostic Interventional TeChNiQues}

A recent review of diagnostic interventional techniques for the spine (33) provided strong evidence of the value of facet joint blocks for diagnosis of facet joint pain and lumbar provocative discography for discogenic pain. The review also showed moderate evidence for sacroiliac joint blocks in the diagnosis of sacroiliac joint pain and for transforaminal epidural injections in the preoperative evaluation of patients with negative or inconclusive imaging studies, but with clinical findings of nerve root irritation.

The emerging popularity of neural blockade as a diagnostic tool in painful conditions is due to several factors. Hogan and Abram (160) described several challenging clinical situations, including the characteristics of chronic spinal pain, which are purely subjective, inexactly defined clinically and uncertain pathophysiology. Precision diagnostic blocks are used to clarify these challenging clinical situations to determine the pathophysiology of clinical pain, the site of nociception, and the pathway of afferent neural signals.

Pivotal to the proper management of chronic pain is the ability to pinpoint an anatomical or structural diagnosis and identify one or more pain generators. Deyo and Weinstein (161) reported that precise anatomical diagnosis was elusive in low back pain and that diagnostic evaluation is often frustrating for physicians and patients. They showed that the history, physical examination, and imaging provide limited information (162). Others have shown that, for purposes of pinpointing an anatomical diagnosis, physical examination is neither reliable nor valid (163). It is often cited that a cause cannot be determined in $85 \%$ of patients with low back pain $(161,162,164-166)$ or, conversely, that a diagnosis is possible in only some $10 \%$ to $15 \%$ of cases (166-168). No technique of physical examination has sufficient reliability and validity to allow a pathophysiologic diagnosis to be made $(164,166)$. Radiographic investigations, including magnetic resonance imaging (MRI), identify only a limited number of conditions with certainty (164).

As early as 1938, Steindler and Luck (144) recommended stringent fulfillment of five criteria to establish a causal connection between local pain and radiation of pain unrelated to direct nerve root compression. These principles of provocation-analgesic response have been integrated into the diagnostic armamentarium of the spinal interventionalist, serving to identify pain generators in the spine. Hirsch (169) in 1948 was the first to use this principle in localizing pain to lumbar discs in subjects with back pain. Lindblom et al $(170,171)$ described concordant pain provocation with saline discal distention and no secondary disc damage on intraoperative disc injections. In the late 1950s, Smith and Nichols (172) and Cloward (173) developed cervical disc injection techniques for evaluating patients with cervical cephalagia and shoulder-girdle pain. Since then, the use of discography has fluctuated as a primary investigative measure for discogenic pain to its abolition and then re-emergence in diagnosing discogenic pain and internal disc disruption (174). In 1971, Mac nab et al (175) evaluated the value of diagnostic selective nerve root blocks in the preoperative evaluation of patients with non-diagnostic imaging studies and radicular symptoms. Since then, numerous developments in diagnostic interventional techniques in spinal pain (30) and other painful conditions have emerged (160). The International Association for the Study of Pain has developed standards for performing diagnostic blocks (176).

In the 1990s, new precision diagnostic tests were developed, and old ones refined, evaluated, and implemented. Thus, with the use of appropriate tests, a diagnosis of chronic spinal pain can be made in at least $50 \%$ of cases and perhaps in as many as $70 \%$ of cases $(33,146,177-180)$. These precision diagnostic techniques include facet or zygapophysial joint blocks, provocative discography, and sacroiliac joint blocks.

Central to the understanding of the structural basis of chronic spinal pain is obtaining a physical diagnosis and validation of patient symptomatology whenever it is feasible rather than discounting emotional involvement. This improved diagnostic precision will remove many of the terms utilized in the past such as "psychogenic," "somatizing," "hysterical," and more recently, "medically unexplained," to describe many pain problems which heretofore have not been amenable to diagnosis. From the beginning, it has been proposed that all controlled blocks ideally should include placebo injections of normal saline. However, modern developments have shown that it may be neither logistical nor ethical to use placebo injections of normal saline in conventional medical practice in each and every patient. Thus, an alternative technique -- the use of comparative local anesthetic blocks on two separate occasions during which the same structure is anesthetized using two local anesthetics 
with different durations of actions -- has been proposed (181-183). The use of comparative local anesthetic blocks with facet joint injections has been validated and found to be reliable against challenges with placebos $(184,185)$.

Hildebrandt (186) published an extensive review on the relevance of nerve blocks in treating and diagnosing low back pain. He described zygapophysial joint blocks, sacroiliac joint blocks, disc stimulation, and nerve root blocks, and concluded that the diagnostic use of neural blockade rests on three premises. First, the pathology causing pain is located in an exact peripheral location, and impulses from this site travel via a unique and consistent neural route. Second, injection of local anesthetic totally abolishes the sensory function of intended nerves and does not affect other nerves. Third, relief of pain after local anesthetic block is attributed solely to the block of the target afferent neural pathway. However, Hildebrandt (186) cautioned that the validity of these assumptions is limited by complexities of anatomy, physiology, and psychology of pain perception and by the effect of local anesthetics on impulse conduction. Hogan and Abram (160) and Raja (187) also cautioned against the indiscriminate use of diagnostic blocks, not only for spinal pain but also other painful conditions. Nonetheless, the rationale for diagnostic joint blocks, lumbar discography, and sacroiliac joint blocks is well established (33).

\section{TheRAPEUTiC INTERVENTIONAL TECHNIQUES}

Recent evaluation of interventional techniques in the management of chronic spinal pain (33) showed moderate to strong evidence for numerous therapeutic interventional techniques, including medial branch blocks and medial branch neurotomy, caudal epidural steroid injections, transforaminal epidural steroid injections, lumbar percutaneous adhesiolysis, intradiscal therapies, and implantable therapies. The rationale for therapeutic interventional techniques in the spine is based upon several considerations. First, cardinal sources of chronic spinal pain, particularly discs and joints, are accessible to neural blockade. Second, removal or correction of structural abnormalities of the spine may fail to cure and may even worsen painful conditions. Third, degenerative processes of the spine and the origin of spinal pain are complex. Fourth, the effectiveness of a large variety of ther- apeutic interventions in managing chronic spinal pain has not been demonstrated conclusively. Interventional techniques in the management of chronic spinal pain include neural blockade and minimally invasive surgical procedures, ranging from epidural injections, facet joint injections, and neuroablation techniques, to intradiscal thermal therapy, disc decompression, morphine pump implantation, and spinal cord stimulation.

Much of the early work with pain perception focused on nociceptive transmission from periphery to the brain. Nonetheless, shortly following the introduction of the gate control theory, another important observation was made, focusing on the descending modulation of pain perception. Parallel to the interest in nociceptive neurophysiology was a developing interest in clinical relief of obscure painful conditions. Causalgia from warrelated nerve injuries and sympathetically mediated pain was recognized (188-190). Brunn and Mandl (81) in 1924, described therapeutic block in the management of visceral pain. In the same year, Royle (82) reported effectiveness for interruption of the sympathetic nerve supply to the musculature of the affected limbs in relieving deformity contractions and spastic paralysis in Little's disease. In 1926 Swetlow (83) reported long-term pain relief by neurolytic injection of alcohol to paravertebral sympathetic nerves in the treatment of severe intractable pain, particularly pain of malignant disease. In 1930 Dogliotti went further and injected absolute alcohol into the subarachnoid space to produce simple chemical posterior rhizotomy equivalent to that previously attainable only by surgery (74).

Sicard (77) first described injection of dilute solutions of cocaine through the sacral hiatus into the epidural space in 1901 to treat patients suffering from severe, intractable sciatic pain or lumbago. Cathelin (78) also described caudal administration of local anesthetic not only for surgical procedures, but also for the relief of pain due to inoperable carcinoma of the rectum (199). Pasquier and Leri (79), also in 1901, independently reported the use of caudal epidural injection for relief of sciatic pain (199).

In 1912, Kappis (85) described paravertebral somatic blocks for surgery and pain relief. In 1922, Läwen (86) used paravertebral somatic block in the diagnosis of abdominal disease. Celiac plexus block was first described by Braun (87), utilizing an anterior surgical approach in 1906, followed by Kappis (88) in 1914, utilizing a posterior approach. Similarly, stellate ganglion or cervical/thoracic sympathetic block was described initially by Labat (89) in 1930, utilizing a posterior approach. Since then, others have described an anterior approach (189) and a paratracheal approach (191). Brachial plexus block emerged following the description by Halsted (192) in 1884 with numerous modifications over the years (193). The evolution has continued with developments in the use of caudal epidural injections, transforaminal epidural injections, percutaneous adhesiolysis, spinal endoscopic adhesiolysis, facet joint interventions, and intradiscal therapies $(33,194-202)$.

\section{Evolution}

In 1953 John J. Bonica nurtured an interest in pain medicine and published a seminal book -- The Management of Pain (198). At the time, much of pain medicine was focused on nerve block clinics. Vandam and Eckenhoff (199), a year after the publication of Bonica's text on the management of pain, suggested that the focus should not only be on pain relief from nerve blocks but also on the basic nature of pain and an integrated approach to treatment. Bonica (200) started a multidisciplinary clinic in 1960 . In 1986, launching the era of interventional pain management, Privthi Raj (201) published the first edition of Practical Management of Pain. In 1993 Waldman and Winnie (202) published the textbook Interventional Pain Management and claimed that the subspecialty of interventional pain management was born. Since then, the specialty has blossomed, with publication of numerous textbooks and new journals concentrating on pain medicine, pain management, and interventional pain management.

Along with- recognition and steady new developments, organizations representing diverse groups of pain physicians have emerged. In 1974, largely as a result of the efforts of John Bonica, the International Association for the Study of Pain (IASP) was born. The American Pain Society, the American chapter of the IASP was established in 1977. The American Academy of Pain Medicine (originally Algology) was founded in 1983. Established in 1988, the American Academy of 
Pain Management is currently the largest multidisciplinary pain management organization in the United States. The largest physician specialty pain management organization in the United States is the American Society of Regional Anesthesia and Pain Medicine. The World Society of Pain Clinicians and the World Institute of Pain also emerged in 1990s. The American Society of Interventional Pain Physicians (originally the Association of Pain Management Anesthesiologists) was founded in 1998 to represent interests of interventional pain physicians and to preserve interventional pain management.

Specialty codes for pain management (-72) and interventional pain management (-09) have been recognized by the Centers for Medicare and Medicaid Services. The National Uniform Claim Committee defined interventional pain management as:

"The discipline of medicine devoted to the diagnosis and treatment of pain and related disorders with the application of interventional techniques in managing subacute, chronic, persistent, and intractable pain, independently or in conjunction with other modalities of treatments."

The Board of Directors of the American Board of Pain Medicine defined the specialty of pain medicine as follows (203):

"The specialty of Pain Medicine is concerned with the prevention, evaluation, diagnosis, treatment and rehabilitation of painful disorders. Such disorders may have pain and associated symptoms arising from a discrete cause, such as postoperative pain or pain associated with malignancy, or may be syndromes in which pain constitutes the primary problem, such as neuropathic pains or headaches. The diagnosis of painful syndrome relies on interpretation of historical data; review of previous laboratory, imaging and electrodiagnostic studies; behavioral, social, occupational and avocational assessment; interview and examination by the pain specialist; and may require specialized diagnostic procedures, including central and peripheral neuro-blockade or monitored drug infusions. The special needs of the pediatric and geriatric populations are considered when formulating a comprehensive treatment plan for these patients."

In an editorial, Lippe (203) wrote that physicians specializing in pain medicine may work in a variety of settings and is competent to treat the entire range of painful disorders encountered in the delivery of quality healthcare. Lippe (203) also stated:

"The field of pain medicine is primarily a nonprocedural specialty. It is not in conflict or in competition with anesthesiologists who subspecialize in pain management nor, for that matter, is it in competition with any other primary specialty that may choose to develop subspecialty expertise in pain management. At all stages of pain management, pain physicians function in a collaborative manner with other specialties and subspecialties. It is already evident that pain physicians have developed a symbiotic relationship with anesthesiologists specializing in pain management, thereby strengthening both fields by mutual cross-fertilization and referral patterns."

Saal (204), describing the past, present, and future of spinal injections, concluded that over the past 20 years, some of the changes have been positive, whereas others have been deleterious. Saal (204) believed that the treatment algorithm currently incorporates injection procedures to facilitate functional improvement. The growing demand for therapeutic and diagnostic injections has given birth to the "injectionist" (i.e., the interventionist). However, Saal (204) felt that this evolutionary phenomenon had led to a departure from the original core values, as interventionists had begun to use or were presumed to use procedures outside of the established algorithm. It was described that many patients were being treated with procedures and medications but never provided rehabilitation to improve function. Likewise, patients with simple back pain were undergoing facet rhizolysis procedures and discography at the top of the algorithm rather than at later stages, as originally intended (204). Saal (204) complained that, "shoot first, ask questions later" was the prevailing motto, with some patients undergoing 20 to 50 epidural injections, and the cost of injection- based work-ups before surgery increasing to as much as $\$ 8,000$ to $\$ 10,000$, without documented improvement in outcomes. However, there is no literature to support this negative view with regards to an algorithmic approach coupled with functional rehabilitation (33).

Board certification by the American Board of Anesthesiology with subspecialty designation by the American Board of Medical Specialties (certificate of added qualifications in pain management, recently changed to pain medicine) was first offered in 1993. The American Board of Pain Medicine (not recognized by the American Board of Medical Specialties) also offers a board examination. Competency certification in Interventional Pain Management has been offered worldwide by the World Institute of Pain since 2002.

\section{Pathophysiologic Basis of Pain}

The value of interventional pain management lies in the concept of a structural basis for pain. In the modern era, this structural basis of chronic pain is extremely important. The concept of psychogenic pain has sparked controversy in the field of pain medicine, not only regarding its prevalence but its very existence (205). Now, psychogenic pain is considered within the context that "since there is nothing wrong with your body, there must be something wrong with you". Some state that the term psychogenic pain is fundamentally meaningless (206). The diagnosis of psychogenic pain not only fails to provide a valid organic diagnosis, but it also fails to provide validation of a patient's symptomatology and complaints. In essence, psychogenic pain implies that persistent pain is either unreal or illusional. The concept of psychogenic pain is weakened by the fact that its diagnostic signs have been challenged. Gagliese and Katz (206) believed that medically unexplained pain is not a symptom of a psychological disorder and that it is time to abandon thinking that separates mind and body. Thus, the challenge remains for proponents of psychogenic pain to provide empirical evidence to support the contention that psychopathology causes pain and, in doing so, to specify the mechanism by which it is generated. Modern technology, including magnetic resonance imaging (MRI), computed tomographic axial scanning (CT), neurophysiologic testing, and comprehensive 
physical examination with psychological evaluation, can identify the cause of low back pain in only $15 \%$ of the patients in the absence of disc herniation and neurological deficit (161-168). Further, overall inaccurate or incomplete diagnosis in patients referred to pain treatment centers has been described as ranging from $40 \%$ to $67 \%$. The above arguments notwithstanding, the incidence of psychogenic pain is only 1 in 3,000 patients $(207,208)$. On the other hand, pain of organic origin was mistakenly branded as psychosomatic in $98 \%$ of cases. Staats et al (209) pointed out that human behavior and pain phenomena are complex, making it impossible to deal with pain in a simple way, referring only to some things but not to others. If, for example, the focus is on the biological aspects of pain, then much will be missed, for learning and personality play pivotal roles. The same thing is true when the focus is on the simple use of behavior principles. Thus, central to an understanding of the structural basis of chronic pain is the provision of a physical diagnosis and validation of the patient's symptomatology, whenever it is feasible, rather than simply discounting unexplained pain to emotional causes. This approach will remove many of the terms utilized in the past, including "psychogenic," "somatizing," "hysterical," and more recently, "medically unexplained," to explain many of the pain problems not amenable to diagnosis by present methodology utilizing physical examination, radiological testing, and electrodiagnostic testing. Identifying a structural basis of pain also will invalidate the theory that maladaptive psychological processes are primarily responsible for causing regional pain syndromes, which lead to the conclusion that psychological or behavorial interventions are the most logical primary treatment modalities.

A structural cause of pain may be identified in $70 \%$ to $80 \%$ of the patients with chronic spinal pain with precision diagnostic techniques following IASP criteria $(33,146,178,180,210)$. In patients without neurological symptoms, disc herniation, and positive nerve conduction studies, diagnostic interventional techniques have shown that facet joints are the source of chronic spinal pain in $15 \%$ to $45 \%$ of the heterogenous groups of patients with chronic low back pain, $48 \%$ of patients with thoracic pain, $54 \%$ to $67 \%$ of patients with chronic neck pain; internal disc disruption in $39 \%$ of patients suffering with chronic low back pain, and primary discogenic pain in $26 \%$ of patients suffering with chronic low back pain demonstrated by provocative discography, and sacroiliac joint pain with controlled local anesthetic blocks in as low as $2 \%$ and as high as $30 \%$ of patients (33).

Interventional pain management, which started with neural blockade and regional anesthetic blocks, has progressed to include well-defined and effective interventional techniques. In modern medicine, with new innovative techniques, drugs, and imaging modalities, the scope of interventional pain management has increased substantially. New research grounded in evidence-based principles is contributing to the steady progress of interventional pain management.

\section{Predictions on the Future of Interventional Pain Management}

The future of interventional pain management requires a proper understanding of the practice of interventional pain management, the appropriate use of interventional techniques, research aimed at elucidating the pathophysiologic basis of pain, studies validating evidence-based approaches for interventional pain management, and a good faith effort to eliminate fraud and abuse.

Interventional pain management is defined as the discipline of medicine devoted to the diagnosis and treatment of pain and related disorders by the application of interventional techniques in managing subacute, chronic, persistent, and intractable pain, independently or in conjunction with other modalities of treatments. It may be employed by pain medicine specialists, spine specialists, surgeons, psychiatrists, and rehabilitation specialists. Implied in the definition of interventional pain management are the terms multidisciplinary, interdisciplinary and comprehensive. The terms multidisciplinary or comprehensive cause significant confusion and are related to a physician's primary specialty. Thus, an interventionalist perceives a multidisciplinary or comprehensive program as one with interventional techniques as the primary modality and physical and psychological modalities as secondary components. In contrast, a psychiatrist, rehabilitation specialist, or surgeon may emphasize psychology/psychiatry, physical therapy/ functional rehabilitation or surgery, with multidisciplinary management provided by secondary application of other modalities, such as interventional techniques. However, no single approach to the treatment of chronic pain has been validated. Evidence-based guidelines for the management of chronic spinal pain have been published, though they are scarce. A few of these were considered as an overview of the large number of treatments currently available in managing chronic pain. It is easy to see that chronic pain management -- not interventional pain management alone -- is a diverse field, characterized by misconceptions, misunderstandings, personal bias, competing concepts and foundations, as well as various historical approaches to the management of pain.

The advent of evidence-based medicine has led to tensions among various specialties. From a historical perspective, the oldest strategies for chronic pain constituted conservative monotherapies and surgical interventions, usually for spinal pain. However, evaluation of monotherapies and multidisciplinary management (with numerous definitions) has yielded contradictory results. Thus, it is essential for interventionalists to define interventional pain management on evidence-based medicine principles.

An additional issue concerns research and publications. The volume of research performed by interventional pain specialists is miniscule compared to the general fields of pain medicine and spine disorders. There are few journals publishing articles on interventional pain management. Evidence-based medicine research, to a great extent, has not included interventional pain management studies; this may reflect the fact the many evidence-based reviews are performed by non-physicians and non-interventionalists. Thus, the need remains for raising the standards of interventional pain management by physicians who practice interventional pain management.

Several organizations have published guidelines for chronic pain management using interventional techniques. None have been universally accepted. Further, there have not been outcomes studies based on these algorithms, opinions, or consensus statements, except for a study published by The American Society of Interventional Pain Physicians (211). 
As physicians, our primary goal is to improve the health and well-being of our patients. The future of interventional pain management is promising, because emerging clinical evidence supports the use of this technology. Yet, uncertainties and ambiguities remain. Increasing healthcare costs, involvement of federal government agencies, decreasing physician reimbursement, and an increasing number of patients with chronic pain create a complex, stressful healthcare environment, for patients and physicians alike. The future of interventional pain management depends on a good faith effort to develop and follow evidence-based standards. Integrity of the reimbursement system requires that physicians also make a good faith effort to comply with regulations and to avoid fraud and abuse. It should be pointed out that physicians who overuse resources, provide poor documentation, or employ "creative billing and coding" techniques, may have a major adverse impact on the future of interventional pain management. Physicians should realize that even in this era of evidence-based medicine, physician judgment, integrity, and patient safety should be placed ahead of profits.

\section{ConcLusion}

Interventional pain management is a separate and distinct medical specialty, recognized by CMS. Pain management, since its inception, has taken many shapes and forms. Although interventional pain management dates back to the origins of neural blockade and regional anesthesia, it evolved into a distinct specialty with the development of new interventional techniques. Fundamental to modern interventional pain management are precision diagnostic and therapeutic interventional techniques, applied judiciously to improve the health and well-being of patients.

\section{Author Affiliation:}

\section{Laxmaiah Manchikanti, MD}

Medical Director

Pain Management Center of Paducah 2831 Lone Oak Road, Paducah, Kentucky 42003

E-mail: drm@apex.net

\section{Mark V. Boswell, MD, PhD}

Associate Professor of Anesthesiology

Chief, Division of Pain Medicine

Department of Anesthesiology

Director, Pain Medicine Fellowship

Program

Case Western Reserve University

School of Medicine and University

Hospitals of Cleveland

11100 Euclid Avenue

Cleveland, Ohio-44106

E-mail: mark.boswell@uhhs.com

\section{P. Prithvi Raj, MD}

Chairman of the Examination Board

WIP- Pain Practice

Texas Tech Medical Center

International Pain Institute

4430 South Loop 289

Lubbock, Texas 79413

E-mail: prithviraj7@attbi.com

Gabor B. Racz, MD

Texas Tech University Health

Sciences Center

36014 th Street

Lubbock, Texas-79430

E-mail: paula.brashear@ttuhsc.edu

\section{REFERENCES}

1. Schweitzer A. On the edge of the primeval forest. New York: Macmillan, 1931:62.

2. Bonica JJ, Loeser JD. History of pain concepts and therapies. In Bonica's Management of Pain. $3^{\text {rd }}$ ed. Loeser JD (ed). Lippincott Williams \& Wilkins, Philadelphia, 2001, pp. 3-16.

3. Castiglioni A. A history of medicine. New York: Knopf, 1947.

4. Fulop-Mueller R. Triumph over pain. Translated by E. and C. Paul. New York: Literary Guild of America, 1938; 7:8.

5. Keele KD. Anatomies of pain. Oxford: Blackwell, 1957.

6. Sigerist HE. A history of medicine. Vol 1. Oxford University Press, New York, 1951; 274:349.

7. Tainter ML. Pain. Ann NY Acad Sci 1948; 51:3-11.

8. Asmundson GJ, Hadjistavropoulos T, Antonishyn M. Profiles and perspectives of the leading contributors in the field of pain. Pain Clin 2001; 13:55-69.

9. Frölich MA, Caton D. Pioneers in epidural needle design. Anesth Analg 2001; 93: 215-220.

10. Gureje O, VonKorff M, Simon GE et al. Persistent pain and well-being: A World Health Organization Study in primary care. JAMA 1998; 280:147-151.

11. Harstall C. How prevalent is chronic pain? Pain Clinical Updates, IASP, 2003; XI; 2:1 4.

12. Andersson $\mathrm{HI}$, Ejlertsson G, Leden I et al. Chronic pain in a geographically defined general population: Studies of differences in age, gender, social class, and pain localization. Clin J Pain 1993; 9:174-182.

13. Blyth FM, March LM, Brnabic AJ et al. Chronic pain in Australia: A prevalence study. Pain 2001; 89:127-134.

14. Elliott AM, Smith BH, Penny KI et al. The epidemiology of chronic pain in the com munity. Lancet 1999; 354:1248-1252.

15. Perquin CW, Hazebroek-Kampschreur AA, Hunfeld JA et al. Chronic pain among children and adolescents: Physician consultation and medication use. Clin J Pain 2000; 16:229-235.

16. Catala E, Reig E, Artes M et al. Prevalence of pain in the Spanish population: Telephone survey in 5000 homes. Eur J Pain 2002; 6:133-140.

17. Helme RD, Gibson SJ. In Jensen TS, Turner IA, Wiesenfeld-Hallin Z (eds). Pain in the Elderly. In Proceedings of the 8th World Congress on Pain. Progress in Pain Research and Management, IASP Press, Seattle, 1997, pp 919-944.

18. International Association for the Study of Pain. Pain 1986; 3:S1-S225.

19. Croft P, Rigby AS, Boswell R et al. The prevalence of chronic widespread pain in the general population. I Rheumatol 1993; 20:710-713.

20. MacFarlane GJ, Morris S, Hunt IM et al. Chronic widespread pain in the community: the influence of psychological symptoms and mental disorder on healthcare seeking behavior. J Rheumatol 1999; 26: 413-419.

21. Buskila D, Abramov G, Biton A et al. The prevalence of pain complaints in a general population in Israel and its implications for utilization of health services. J Rheumatol 2000; 27:1521-1525.

22. Wolfe F, Smythe HA, Yunus MB et al. The American College of Rheumatology 1990 Criteria for the Classification of Fibromyalgia. Report of the Multicenter Criteria Committee. Arthritis Rheum 1990; 33:160172.

23. Brochet, $P$ Michel, $P$ Barberger-Gateau et al. Population-based study of pain in elderly people: a descriptive survey. Age Ageing 1998; 27:279-284

24. Schnitzer TJ. Non-NSAID pharmacologic treatment options for the management of chronic pain. Am J Med 1998; 105:45S- 
$52 S$.

25. Hill CS. When will adequate pain treatment be the norm? JAMA 1995; 274:18811882.

26. Dahl JL. Improving the practice of pain management. JAMA 2000; 284:2785.

27. Verhaak PFM, Kerssens JJ, Dekker J et al. Prevalence of chronic benign pain disorder among adults: A review of the literature. Pain 1998; 77:231-239.

28. Bressler HB, Keyes WJ, Rochon PA et al. The prevalence of low back pain in the elderly. A systemic review of the literature. Spine 1999; 24:1813-1819.

29. Asch SM, Sloss EM, Hogan C et al. Measuring underuse of necessary care among elderly Medicare beneficiaries using inpatient and outpatient claims. JAMA 2000; 284:2325-2333.

30. Cousins MJ. Pain: The past, present, and future of anesthesiology? The E.A. Rovenstine Memorial Lecture. Anesthesiology 1999; 91:538-551.

31. Hoffmann DE. Pain management and palliative care in the era of managed care: Issue for health insurers. J Law, Med \& Ethics 1998; 26:267-289.

32. Pahor M, Guralnik JM, Wan JY. Lower body osteoarticular pain and dose of analgesic medications in older disabled women: The Women's Health and Aging Study. Am J Public Health 1999; 89:930-934.

33. Manchikanti L, Staats $P$, Singh $V$ et al. Evidence-based practice guidelines for interventional techniques in the management of chronic spinal pain. Pain Physician 2003; 6:3-80.

34. Schmidt AP, Schmidt SR. How effective are opioids in relieving neuropathic pain? Pain Clinic 2002; 14:183-193.

35. Moulin DE, Clark AJ, Speechley $M$ et al. Chronic pain in Canada - prevalence, treatment, impact and the role of opioid analgesia. Pain Res Manage 2002; 7:179184.

36. Elliott AM, Smith BH, Hannaford PC et al. The course of chronic pain in the community: Results of a 4-year follow-up study. Pain 2002; 99:299-307.

37. Yeung SS, Genaidy A, Deddens J et al. Prevalence of musculoskeletal symptoms in single and multiple body regions and effects of perceived risk of injury among manual handling workers. Spine 2002; 27:2166-2172.

38. Crombie IK, Croft PR, Linton SJ et al (eds) Epidemiology of pain: A report of task force on epidemiology of the International Association for the Study of Pain. IASP Press, Seattle 1999.

39. Ferrell BR, Ferrell BA (eds). Pain in the elderly. A report of the task force on pain in the elderly of the international association for the study of pain. IASP Press, Seattle, 1996.

40. Lawrence RC, Helmick CG, Arnett FC. Estimates of the prevalence of arthritis and selected musculoskeletal disorders in the
United States. Arthritis Rheum 1998; 41: 778-799.

41. Barajas C, Bosch F, Baños J. A pilot survey of pain prevalence in schoolchildren. Pain Clin 2001; 13:95-102.

42. Currie C, Hurrelmann K, Settertobulte W et al. Health and health behavior among young people. Health behavior in schoolaged children: A WHO cross-national study (HBSC) international report, 2002:1-134; www.ruhbc.ed.ac.uk/hbsc/ index.html.

43. Salminen JJ, Erkintalo MO, Pentti J et al. Recurrent low back pain and early disc degeneration in the young. Spine 1999; 24: 1316-1321.

44. Hellsing A, Bryngelsson I. Predictors of musculoskeletal pain in men. A twentyyear follow-up from examination at enlistment. Spine 2000; 25:3080-3086.

45. Papageorgiou AC, Croft PR, Ferry $S$ et al. Estimating the prevalence of low back pain in the general population: Evidence from the South Manchester back pain survey. Spine 1995; 20:1889-1894.

46. Walker BF. The prevalence of low back pain in Australian adults. A systematic review of the literature from 1966-1998. Asia Pac J Public Health 1999; 11:45-51.

47. Waxman R, Tennant A, Helliwell P. A prospective follow up study of low back pain in the community. Spine 2000; 25:20852090.

48. Cassidy D, Carroll L, Cotê P: The Saskatchewan Health and Back Pain Survey. The prevalence of low back pain and related disability in Saskatchewan Adults. Spine 1998; 23:1860-1867.

49. Leboeuf-Yde C, Lauritsen JM. The prevalence of low back pain in the literature. A structured review of 26 Nordic studies from 1954 to 1993. Spine 1995; 20:21122118.

50. Bovim G, Schrader H, Sand T. Neck pain in the general population. Spine 1994; 19: 1307-1309.

51. Côté DC, Cassidy JD, Carroll L. The Saskatchewan Health and Back Pain Survey. The prevalence of neck pain and related disability in Saskatchewan adults. Spine 1998; 23:1689-1698.

52. Croft PR, Lewis M, Papageorgiou AC et al. Risk factors for neck pain: A longitudinal study in the general population. Pain 2001; 93:317-325.

53. Linton SJ, Hellsing AL, Hallden K. A population based study of spinal pain among 35-45-year old individuals. Spine 1998; 23:1457-1463.

54. Occhipiniti E, Colombini D, Grieco A. Study of distribution and characteristics of spinal disorders using a validated questionnaire in a group of male subjects not exposed to occupational spinal risk factors. Spine 1993; 18:1150-1159.

55. Schiottz-Christensen B, Nielsen GL, Hansen VK et al. Long-term prognosis of acute low back pain in patients seen in general practice: A 1-year prospective follow-up study. Fam Pract 1999; 16:223-232.

56. Ferguson SA, Marras WS, Gupta P. Longitudinal quantitative measures of the natural course of low back pain recovery. Spine 2000; 25:1950-1956.

57. Vingård $\mathrm{E}$, Mortimer $\mathrm{M}$, Wiktorin $\mathrm{C}$ et al. Seeking care for low back pain in the general population: A two-year follow-up study: Results from the MUSIC-Norrtalje Study. Spine 2002; 27:2159-2165.

58. Rosenblum A, Joseph H, Fong C et al. Prevalence and characteristics of chronic pain among chemically dependent patients in methadone maintenance and residential treatment facilities. JAMA 2003; 289: 2370-2378.

59. McNeil J. Americans with disabilities, 1994-95. Washington, DC: US Department of Commerce, Economics and Statistics Administration, Bureau of the Census, 1997. (Current population reports; series P70, no. 61).

6o. Hough J. Estimating the health care utilization costs associated with people with disabilities: Data from the 1996 Medical Expenditure Panel Survey (MEPS). Annual meeting of the Association for Health Services Research, Los Angeles, California, 2000.

61. Leigh JP, Markowitz S, Fahs M et al. Occupational injury and illness in the United States. Estimates of costs, morbidity, and mortality. Arch Intern Med 1997; 157: 1557-1568.

62. CDC. Prevalence of disabilities and associated health conditions among adults United States, 1999. MMWR 2001; 50:120125.

63. Freedman VA, Martin LG, Schoeni RF. Recent trends in disability and functioning among older adults in the united states. JAMA 2002; 288:3137-3146.

64. Cousins MJ. Foreword. In Fordyce WE (ed). Back pain in the workplace: Management of disability in nonspecific conditions. Task Force Report. Seattle: IASP Press, 1995, p ix.

65. de Lissovoy G, Brown RE, Halpern M et al. Cost-effectiveness of long-term intrathecal morphine therapy for pain associated with failed back surgery syndrome. Clin Ther 1997; 19:96-112.

66. Simmons J, Avant W, Demski J et al. Determining successful pain clinic treatment through validation of cost effectiveness. Spine 1988; 13:24-34.

67. Bell G, Kidd D, North R. Cost-effectiveness analysis of spinal cord stimulation in treatment of failed back surgery syndrome. J Pain Symp Manage 1997; 13:286-295.

68. Turk DC. Clinical effectiveness and costeffectiveness of treatments for patients with chronic pain. Clin J Pain 2002; 18: 355-365.

69. Straus BN. Chronic pain of spinal origin. Spine 2002; 27:2614-2619.

70. Melzack R, Wall P. Pain mechanisms: A new theory. Science 1965; 150:971-979.

71. Jensen TS, Turner JA, Wiesenfeld-Hallin Z. 
In Proceedings of the $8^{\text {th }}$ World Congress on Pain. IASP Press, Seattle, 1997.

72. Merskey $\mathrm{H}$. History of pain research and management in Canada. Pain Res Manage 1998; 3:164-173.

73. Strassels SA, Carr DB, Meldrum M et al. Toward a canon of the pain and analgesia literature: A citation analysis. Anesth Analg 1999; 89:1528-1533.

74. Brown DL, Fink BR. The history of neural blockade and pain management. In Cousins MJ, Bridenbaugh PO (eds). Neural Blockade in Clinical Anesthesia and Management of Pain. $3^{\text {rd }}$ ed. Lippincott-Raven, Phaldelphia, 1998, pp. 3-34

75. Tuffer T. Anesthésie medullaire chirurgicale par injection sousarachnoidienne lombiare de cocaine; technique et resultats. Semaine Medicale 1900; 20:167.

76. Cushing $\mathrm{H}$. On the avoidance of shock in major amputations by cocainization of large nerve-trunks preliminary to their division. Ann Surg 1902; 36:321.

77. Sicard MA. Les injections medicamenteuse extraduraqles per voie saracoccygiene. Comptes Renues des Senances de la Societe de Biolgie et de ses Filliales, 1901; 53:396-398.

78. Cathelin F. Mode d'action de a cocaine injete daus l'escapte epidural par le procede du canal sacre. Comptes Rendies des Senaces de la Societe de Biologic et de ses Filliales, 1901; 53:452-453.

79. Pasquier NM, Leri D. Injection intra-et extradurales de cocaine a dose minime daus le traitment de la sciatique. Bull Gen Ther 1901; 142:196.

80. Schloesser H. Heilung periphärfer Reizzustände sensibler und motorischer Nerven. Klin Monatsbl Augenheilkd 1903; 41: 255.

81. Brunn F, Mandl F. Die paravertebral Injektion zur Bekäampfung visceraler Schmerzen. Wien Klin Wochenschr 1924; 37:511.

82. Royle ND. A new operative procedure in the treatment of spastic paralysis and its experimental basis. Med J Aust 1924; 1: 77.

83. Swetlow GI. Paravertebral alcohol block in cardiac pain. Am Heart J 1926; 1:393.

84. Sise LF. Spinal anesthesia for upper and lower abdominal operations. N Engl J Med 1928; 199:61.

85. Kappis M. ueber Leitungsanästhesie an Bauch, Burst, Arm und Hals durch Injektion ans Foramen intervertebrale. Münch. Med Wochenschr 1912; 1:794.

86. Läwen A. Ueber segmentäre Schmerzaufhebung durch papavertebrale Novokaininjektionen zur Differentialdiagnose intra-adbominaler Erkrankungen. Med Wochenschr 1922; 69:1423.

87. Braun H. Ueber einige neuer örtliche Anaesthetica (Stovain, Alypin, Novocain). Dtsch Klin Wochenschr 1905; 31:1667.

88. Kappis M, Erfahrungen mit Lokalanästhesie bei Bauchoperationen. Verh Dtsch Ges Chir 1914; 43:87.
89. Labat G. Circulatory disturbances associated with subarachnoid nerve block. Long Island Med J 1924; 21:573.

90. Wertheim HM, Rovenstine EA. Suprascapular nerve block. Anesthesiology 1941; 2: 541.

91. Caussade G, Queste P. Traitement de al neuralgie sciatique par la mèthode de Sicard. Résultats favorables même dans les cas chroniues par la cocaïne à doses élevées et répétées à intervalles raproches. Bull Soc Med Hosp Paris 1909; 28:865.

92. Sicard JA, Forestier J: Methode radiographique d'exploration de la cavite epidurale par le Lipiodol. Rev Neurol 1921; 2: 1264.

93. Viner N. Intractable sciatica-The sacral epidural injection-An effective method of giving pain relief. Can Med Asso J 1925; 15:630-634.

94. Evans W. Intersacral epidural injection in the treatment of sciatica. Lancet 1930; 2: 1225-1229.

95. Bresgen C. Uber Ischiassimulation die diagnostische. Bedeutung der epidural Novocaininjection. München Med Wchnschr 1951; 93:934

96. Cappio M. Il trattamento idrocortisonico per via epidurale sacrale delle lombosciatalgie. Reumatismo 1957; 9:60-70.

97. Brown JH. Pressure caudal anesthesia and back manipulation. Northwest Med 1960; 59: 905-909.

98. Ombregt L, Ter Veer HJ. Treatment of the lumbar spine. In Ombregt L, Bisschop P, Ter Veer $\mathrm{HJ}$ et al (eds). A System of Orthopaedic Medicine. WB Saunders, London, 1995, pp 633-688.

99. Cyriax JH. Epidural anesthesia and bedrest in sciatica. Br Med J 1961; 1:20-24

100. Goebert HW, Jallo SJ, Gardner WJ et al. Painful radiculopathy treated with epidural injections of procaine and hydrocortisone acetate: Results in 113 patients. Anesth Analg 1961; 140:130-134.

101. Bogduk N, Christophidis N, Cherry D et al. Epidural Use of Steroids in the Management of Back Pain. Report of Working Party on Epidural Use of Steroids in the Management of Back Pain. National Health and Medical Research Council. Commonwealth of Australia, Canberra, 1994, pp 176.

102. Robechhi A, Capra R. L'idrocortisone (composto F). Prime esperienze cliniche in campo reumatologico . Minerva Med 1952; 98:1259-1263.

103. Biella A, Cocognini P. L'acetato di idrocortisone nel trattamento della sindrome sciatalgica. Minerva Med 1954; 1:1863-1865.

104. Cappio M, Fragasso V. Osservazioni sull'uso dell'idroscortisone per via eidurale ed endorachidea nelle lombosciatalgie. Riforma Med 1955; 22:605-607.

105. Cappio M, Fragasso V. Il prednisone per via epidurale sacrale nelle lombosciatalgie. Reumatismo 1957; 5:295-298.
106. Fragasso V. II prednisolone idrosolubile per via epidurale sacrale nelle lombosciatalgie. Gaz Med Ital 1959; 118:358-360.

107. Canale L. II desametazone per via eidurale sacrale nelle lombosciataligie. Gaz Med Ital 1963; 122:210-213.

108. Lievre JA, Block-Mechel H, Pean G, et al. L’hydrocortisone en injection locale. Rev Rhum 1953; 20:310-311.

109. Gerest MF. Le traitement de la nevralgie sciatique par les injections epidurales d'hydrocortisone. J Med Lyon 1958; 261264.

110. Renier JC. L'infiltration epidurale par le premier trou sacre posterieur. Revue du Rhumatisme et des Maladies Osteo-articulaire 1959; 26:526-532.

111. Gilly R. essai de traitement de 50 cas de sciatiques et de radiculalgies lombaires par le Clestene chronodose en infiltrations paradiculaire. Marseille Medicale 1970; 107:341-345.

112. Tajima T, Furukawa K, Kuramochi E. Se lective lumbosacral radiculography and block. Spine 1980; 5:68-77.

113. Racz GB, Holubec JT. Lysis of adhesions in the epidural space. In Racz GB (ed), Techniques of Neurolysis. Kluwer Academic Publishers, Boston, 1989, pp 57-72.

114. Racz GB, Haynsworth RF, Lipton S. Experiences with an improved epidural catheter. Pain Clinic 1986; 1:21-27.

115. Saberski L, Brull S. Spinal and epidural endoscopy: A historical review. Yale J Bio Med 1995; 68:7-15.

116. Burman MS. Myeloscopy or the direct visualization of the spinal cord. J Bone Joint Surg 1931; 13:695-696.

117. Pool JL. Direct visualization of dorsa nerve roots of the cauda equina by means of a myeloscope. Arch Neurol 1938; 39: 1308-1312.

118. Goldthwait JE. The lumbosacral articulation: an explanation of many cases of lum bago, sciatica, and paraplegia. Boston Med and Surg J 1911; 164:365-372.

119. Ghormley RK. Low back pain, with special reference to the articular facets, with presentation of an operative procedure. 1933; 101:1773.

120. Badgley CE. The articular facets in relation to low back pain and sciatic radiation. Bone Joint Surg 1941; 23:481.

121. Hirsch D, Inglemark B, Miller M. The ana tomical basis for low back pain. Acta Orthop Scand 1963; 33:1.

122. Mooney V, Robertson J. The facet syndrome. Clin Orthop 1976; 115:149-156.

123. Pawl RP. Headache, cervical spondylosis, and anterior cervical fusion. Surg Ann 1977; 9:391-498

124. McCall IW, Park WM, O’Brien JP. Induced pain referral from posterior elements in normal subjects. Spine 1979; 4:441-446.

125. Bogduk N, Marsland A. The cervical zyg apophyseal joints as a source of neck pain. Spine 1988; 13:610-617. 
126. Kuslich SD, Ulstrom CL, Michael CJ. The tissue origin of low back pain and sciatica: A report of pain response to tissue stimulation during operation on the lumbar spine using local anesthesia. Orthop Clin North Am 1991; 22:181-187.

127. Dwyer A, Aprill C, Bogduk N. Cervical zygapophyseal joint pain patterns: a study in normal volunteers. Spine 1990; 6:453457.

128. Dreyfuss P, Tibiletti C, Dreyer SJ. Thoracic zygapophyseal joint pain patterns: a study in normal volunteers. Spine 1994; 19:807811.

129. Aprill C, Dwyer A, Bogduk N. The prevalence of cervical zygapophyseal joint pain patterns II: a clinical evaluation. Spine 1990;6:458-461.

130. Manchikanti L, Singh V, Pampati V et al. Evaluation of the relative contributions of various structures in chronic low back pain. Pain Physician 2001; 4:308-316.

131. Mullan S, Hekmatpanah J, Dobbin G et al. Percutaneous intramedullary cordotomy utilizing the unipolar anodal electrolytic lesion. J Neurosurg 1965; 22:548-553.

132. Rosomoff HL, Carroll F, Brown J et al. Percutaneous radiofrequency cervical cordotomy technique. J Neurosurg 1965; 23;639644 .

133. Sweet WH, Wepsic JG. Controlled thermocoagulation of trigeminal ganglion and rootlets for differential destruction of pain fibres. J Neurosurg 1974; 40:143-156.

134. Shealy CN. Percutaneous radiofrequency denervation of the lumbar facets. J Neurosurg 1975; 43:448-451.

135. Cosman E. Radionics, Burlington MA. Personal communication, 1996

136. Sluijter ME, Mehta M. Treatment of chronic back and neck pain by percutaneous thermal lesions. In Lipton S, Miles J (eds). Persistent Pain, Modern Methods of Treatment. Vol. 3. Academic Press, London, Toronto, Sydney, 1981:141-179.

137. Sluijter ME. The use of radiofrequency lesions for pain relief in failed back patients. Int Disabil Stud 1988; 10:37-42.

138. Van Kleef M, Barendse GA, Wilmink JT et al. Percutaneous intradiscal radiofrequency thermocoagulation in chronic non-specific low back pain. A pilot study. Pain Clin 1996; 9:259-268.

139. Barendse GA, van den Berg SG, Kessels $\mathrm{AH}$ et al. Randomized controlled trial of percutaneous intradiscal radiofrequency thermocoagulation for chronic discogenic pain. Lack of effect from a 90-second $70 \mathrm{C}$ lesion. Spine 2001; 26:287-292.

140. Saal JS, Saal JA. Management of chronic discogenic low back pain with a thermal intradiscal catheter. Spine 2000; 25:382388.

141. Hoppenstein R. A new approach to the failed back syndrome. Spine 1980; 5:371379.

142. von Gaza W. Die Resektion der paravertebralen Nerven und die isolierte Durchsch- neidung des Ramus communicans. Arch Klin Chir 1924; 133:479.

143. White JC. Diagnostic novocaine block of the sensory and sympathetic nerves. A method of estimating the results which can be obtained by their permanent interruption. Am J Surg 1930; 9:264.

144. Steindler A, Luck JV. Differential diagnosis of pain in the low back: Allocation of the source of the pain by the procaine hydrochloride method. JAMA 1938; 110:106113.

145. Bogduk N. The clinical anatomy of the cervical dorsal rami. Spine 1982; 7:35-45.

146. Bogduk N. Clinical Anatomy of the Lumbar Spine and Sacrum. Ed. 3. Churchill Livingstone, New York, 1997.

150. Bogduk N. Low back pain. In Clinical Anatomy of the Lumbar Spine and Sacrum, ed 3. Churchill Livingstone, New York, 1997; pp 187-214.

147. Kuslich SD, Ulstrom CL, Michael CJ. The tissue origin of low back pain and sciatica: A report of pain response to tissue stimulation during operation on the lumbar spine using local anesthesia. Orthop Clin North Am 1991; 22:181-187.

148. Manchikanti L, Singh V, Fellows B. Structural basis of chronic low back pain. In Manchikanti L, Slipman CW, Fellows B (eds), Interventional Pain Management: Low Back Pain - Diagnosis and Treatment. ASIPP Publishing, Paducah, KY 2002; 7796.

149. Cavanaugh JM, Ozaktay AC, Yamashita T et al. Mechanisms of low back pain: A neurophysiologic and neuroanatomic study. Clin Orthop 1997; 335:166-180.

151. Bogduk N, Wilson AS, Tynan W. The human lumbar dorsal rami. J Anat 1982; 134: 383-397.

152. Bogduk N. The innervation of the lumbar spine. Spine 1983; 8:286-293.

153. Chua WH, Bogduk N. The surgical anatomy of thoracic facet denervation. Acta Neurochir 1995; 136:140-144.

154. Bogduk N, Windsor M, Inglis A. The innervation of the cervical intervertebral discs. Spine 1988; 13:2-8.

155. Mendel T, Wink CS, Zimny ML. Neural elements in human cervical intervertebral discs. Spine 1992; 17:132-135.

156. Bogduk N, Tynan W, Wilson AS. The innervation of the human lumbar intervertebral discs. J Anat 1981; 132:39-56.

157. Fortin JD, Kissling RO, O'Connor BL et al. Sacroiliac joint innervation and pain. $A m$ J Orthop 1999; 28:687-690.

158. Fortin JD, Dwyer AP, West S, Pier J. Sacroiliac joint. Pain referral maps upon applying a new injection/arthrography technique. Part I. Asymptomatic volunteers. Spine 1994 19: 1475-1482.

159. Fortin JD, Aprill CN, Ponthieux B et al. Sacroiliac joints: Pain referral maps upon applying a new injection/arthrography technique. Part II: Clinical evaluation. Spine 1994; 19:1483-1489. 16o. Hogan QH, Abram SE. Neural blockade for diagnosis and prognosis. Anesthesiology 1997; 86:216-241.

161. Deyo RA, Weinstein JN. Low back pain. $N$ Engl I Med 2001; 344:363-370.

162. Deyo RA, Rainville J, Kent DL. What can the history and physical examination tell us about low back pain? JAMA 1992; 268: 760-765.

163. Bogduk N, McGuirk B (editors). Precision diagnosis. In: Medical Management of Acute and Chronic Low Back pain. An Evidence-Based Approach: Pain Research and Clinical Management, Vol. 13. Amsterdam, Elsevier Science BV, 2002, pp 169176.

164. Bogduk N, McGuirk B (editors). Assessment. In Medical Management of Acute and Chronic Low Back pain. An EvidenceBased Approach: Pain Research and Clinical Management, Vol. 13. Amsterdam: Elsevier Science BV, 2002, pp. 127-38.

165. Kirwan EO. Back pain. In Wall PD, Melzack R (eds). Text Book of Pain. $2^{\text {nd }}$ ed. Churchill Livingstone, Edinburgh, 1989, pp 335-340.

166. Bogduk N, McGuirk B (eds). Causes and sources of chronic low back pain. In Medical Management of Acute and Chronic Low Back pain. An Evidence-Based Approach: Pain Research and Clinical Management, Vol. 13, Elsevier Science BV, Amsterdam, 2002. pp. 115-126.

167. Frymoyer W. Epidemiology. In Frymoyer JW, Gordon SL (eds). New Perspectives on Low Back Pain. American Academy of Orthopaedic Surgeons, Park Ridge, 1989, pp. 19-33.

168. Quebec Task Force on Spinal Disorders. Scientific approach to the assessment and management of activity-related spinal disorders: A monograph for clinicians. Spine 1987; 12:S1-59.

169. Hirsch C. An attempt to diagnose level of disc lesion clinically by disc puncture. Acta Orthop Scand 1948; 18:131-140.

170. Lindblom K. Diagnostic puncture of the intervertebral discs in sciatica. Orthop Scand 1948; 17:231-239.

171. Lindblom K. Technique and results of diagnostic disc puncture and injection (discography) in the lumbar region. Acta Irtigio Iscabd 1951; 20:315-326.

172. Smith GW, Nichols P Jr. Technic for cervical discography. Radiology 1957; 68:718720.

173. Cloward RB. Cervical discography. Technique, indications, and use in the diagnosis of ruptured cervical discs. Am J Roentg 1958; 79:563-574.

174. Fortin JD. Precision diagnostic disc injections. Pain Physician 2000; 3:271-288.

175. Macnab I. Negative disc exploration: An analysis of the causes of nerve root involvement in sixty-eight patients. J Bone Joint Surg 1971; 53A:5891-5903.

176. Merskey H, Bogduk N (editors). Classification of chronic pain. In: Descriptions 
of Chronic Pain Syndromes and Definition of Pain Terms, $2^{\text {nd }}$ ed. Seattle: IASP Press, 1994, pp. 180-181.

177. Bogduk N. International Spinal Injection Society guidelines for the performance of spinal injection procedures. Part 1: Zygapophyseal joint blocks. Clin J Pain 1997; 13:285-302.

178. Bogduk N, McGuirk B (editors). An algorithm for precision diagnosis. In Medical Management of Acute and Chronic Low Back pain. An Evidence-Based Approach: Pain Research and Clinical Management, Vol. 13, Amsterdam: Elsevier Science BV, 2002. pp. $177-186$

179. Bogduk N, McGuirk B (editors). Precision treatment. In Medical Management of Acute and Chronic Low Back pain. An Evidence-Based Approach: Pain Research and Clinical Management, Vol. 13, Amsterdam: Elsevier Science BV, 2002, pp. 187198.

180. Bogduk N, McGuirk B (editors). An approach to chronic low back pain. In Medical Management of Acute and Chronic Low Back pain. An Evidence-Based Approach: Pain Research and Clinical Management, Vol. 13, Amsterdam: Elsevier Science BV, 2002. pp. 199-204.

181. Bonica JJ. Local anesthesia and regional blocks. In Wall PD, Melzack R (eds). Textbook of Pain, Second edition. Churchill Livingstone, Edinburg, 1989, pp 724-743.

182. Bonica JJ, Buckley FP. Regional analgesia with local anesthetics. In Bonica JJ (ed). The Management of Pain. Lea \& Febiger, Philadelphia, 1990; 2:1883-1966.

183. Boas RA. Nerve blocks in the diagnosis of low back pain. Neurosurg Clin North Am 1991; 2:806-816.

184. Barnsley L, Lord S, Bogduk N. Comparative local anesthetic blocks in the diagnosis of cervical zygapophysial joints pain. Pain 1993; 55:99-106.

185. Lord SM, Barnsley L, Bogduk N. The utility of comparative local anesthetic blocks versus placebo-controlled blocks for the diagnosis of cervical zygapophysial joint pain. Clin J Pain 1995; 11:208-213.

186. Hildebrandt J. Relevance of nerve blocks in treating and diagnosing low back pain is the quality decisive? Schmerz 2001; 15: 474-483.

187. Raja SN. Nerve blocks in the evaluation of chronic pain: A plea for caution in their use and interpretation. Anesthesiology 1997; 86:4-6.

188. Mithcell SW, Moorehouse GR, Keen WW. Gunshot wounds and other injuries of nerves. JB Lippincott, Philadelphia, 1864.

189. Leriche R. De la causalgie envisagée comme une nevrité du sympathique et son traitement par la denudation et l'excision de plexus nerveux péiartériels. Presse Med 1916; 24:178.

190. Bonica JJ (ed). Causalgia and other reflex sympathetic dystrophies. In The Management of Pain. $2^{\text {nd }}$ ed. Lea and Febiger, Philadelphia, 1990, p. 220-221.

191. Papper EM. Regional anesthesia: A critical assessment of its place in therapeutics. Anesthesiology 1967; 28:1074-1084.

192. Halsted WS. Surgical Papers by William Steward Halstead. Johns Hopkins Press, Baltimore, 1924; 1:37-39.

193. Brown DL, Bridenbaugh LD. The upper extremity: Somatic block. In Cousins MJ, Bridenbaugh PO (eds). Neural Blockade in Clinical Anesthesia and Management of Pain. $3^{\text {rd }}$ ed. Lippincott-Raven Publishers, Philadelphia, 1998, pp 345-372.

194. Loeser JD. Bonica's Management of Pain. Lippincott, Williams \& Wilkins, Philadelphia, 2001.

195. Raj PP. Practical Management of Pain. Mosby, Philadelphia, 2000.

196. Waldman SD. Interventional Pain Management. WB Saunders, New York, 2001.

197. Manchikanti L, Slipman C, Fellows B (eds). Interventional Pain Management: Low Back Pain: Diagnosis and Treatment, ASIPP
Publishing, Paducah, KY 2002.

198. Bonica JJ. The Management of Pain. Lea $\&$ Febiger, Philadelphia, 1953.

199. Vandam LD, Eckenhoff JE. The anesthesiologist and therapeutic nerve block: Technician or physician? Anesthesiology 1954 15:89.

200. Bonica JJ. Basic principles in managing chronic pain. Arch Surg 1977; 112:783.

201. Raj PP. Practical Management of Pain. Mosby, New York, 1986.

202. Waldman SD, Winnie AP. Interventional Pain Management. WB Saunders, New York, 1993.

203. Lippe PM. Conceptual construct of the specialty of pain medicine. Clin J Pain 1997; 13:183-185.

204. Saal JA. Spinal injections: Past, present and future. Spine J 2001; 387-389.

205. Covington EC. Psychogenic pain -What it means, why it does not exist, and how to diagnose it. Pain Med 2000; 1:287-294.

206. Gagliese L, Katz J. Medically unexplained pain is not caused by psychopathology. Pain Res Manage 2000; 5:251-257.

207. Hendler NH, Bergson C, Morrison C. Overlooked physical diagnoses in chronic pain patients involved in litigation. Part 2. Psychosomatics 1996; 37:509-517.

208. Hendler NH, Kolodny AL. Using medication wisely in chronic pain. Patient Care 1992; 15:125.

209. Staats PS, Hekmat H, Staats AW. The psychological behaviorism theory of pain: A basis for unity. Pain Forum 1996; 5:194207.

210. Pang WW, Mok MS, Lin ML et al. Application of spinal pain mapping in the diagnosis of low back pain-analysis of 104 cases. Acta Anaesthesiol Sin 1998; 36:71-74.

211. Manchikanti L, Rivera J, Pampati $V$ et al. Effectiveness of clinical guidelines in interventional pain management. Pain Physician 2002; 5:127-132. 